\title{
No.2
}

Special Report

COVID-19
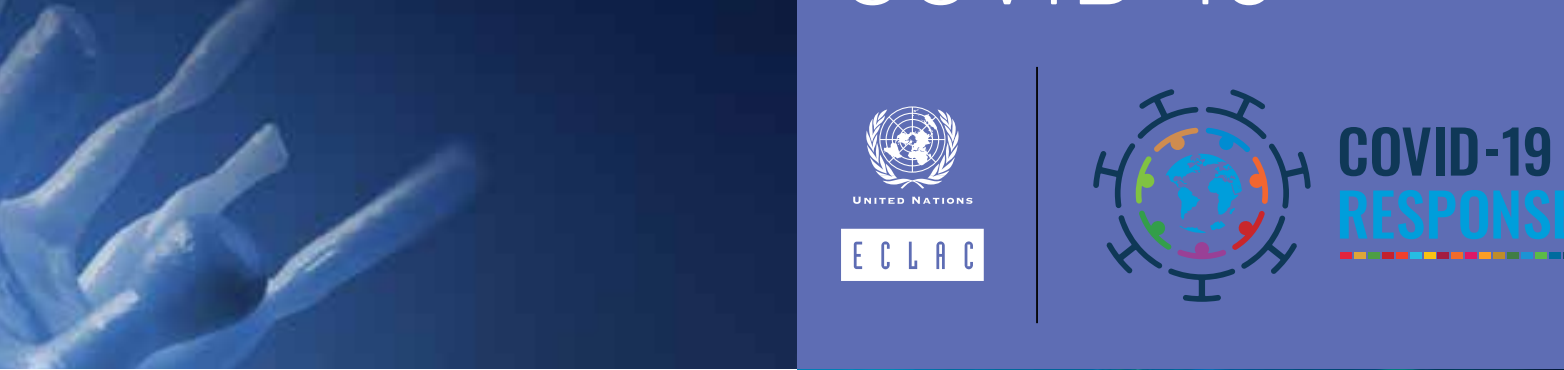

21 April 2020

\section{Measuring the impact of COVID-19 with a view to reactivation}

\section{A. Before the pandemic, growth in Latin America and the Caribbean was at its weakest in decades and policy space was limited}

- The COVID-19 pandemic has hit Latin America and the Caribbean in a period of economic weakness and macroeconomic vulnerability. In the decade following the global financial crisis (2010-2019), regional GDP growth fell from 6\% to $0.2 \%$. Moreover, growth in the 2014-2019 period was the lowest level recorded since the 1950s $(0.4 \%$ ) (see figure 1 and the first report of this series).

- As the pandemic spreads across the region, its nature as a health, economic and social crisis is increasingly evident. The extent and duration of its effects, although still too uncertain to quantify, are becoming clearer. It will result in the region's worst economic and social crisis in decades, with damaging effects on employment, the fight against poverty and the reduction of inequality.

- The aim of this second Special Report is to quantify the economic impact of the pandemic in the short and medium term. With regard to the short term - during the course of 2020 - estimates shed light on the dynamics of production, employment, poverty and income distribution, based on data available at 17 April 2020, for all the subregions of Latin America and the Caribbean and many of their economies. The report also provides details of the main macroeconomic policy measures to tackle the effects of the pandemic that have been announced to date.

Quantifying the decline in economic activity enables authorities to determine the magnitude of the effort required for a return to normal. However, this return to normal will not and should not mean going back to the way things were before the pandemic. The medium-term vision that concludes this report describes the structural changes in the organization of production that are already under way and are expected to gather pace. There will also be impacts — in some cases irreversible - on the labour structure, employment and well-being.

- Quantitative estimates for the short term, combined with forecasts of the main qualitative changes in the medium term, will shape what will become a new normal.

\section{Contents}

A. Before the pandemic, growth in Latin America and the Caribbean was at its weakest in decades and policy space was limited.

B. The pandemic will lead to the most severe contraction in economic activity in the region's history

C. Policy responses to tackle the economic and social effects of the pandemic

D. Growth projections for 2020 for the countries of Latin America and the Caribbean.

E. Macroeconomic policy challenges for continuing to mitigate the effects of the crisis

F. Structural effects of the pandemic: the post-COVID 19 world. 18

Bibliography. 21 
Figure 1 | Latin America and the Caribbean: real GDP growth, 1951-2019 (Percentages)

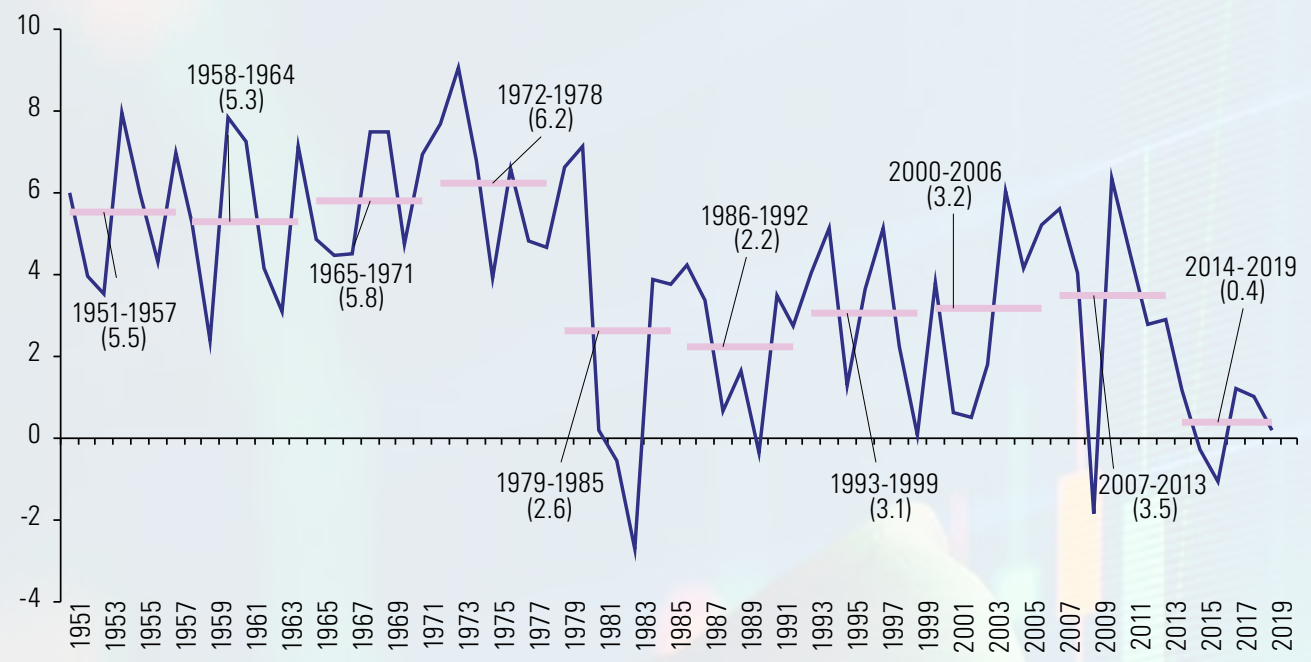

Source: Economic Commission for Latin America and the Caribbean (ECLAC), on the basis of official figures.

\section{The region has little room to increase fiscal spending owing to high debt, rising interest payments and limited tax revenue}

- The accumulation of fiscal deficits in Latin America (2.7\% on average in the past decade) increased central governments' gross public debt, which in 2019 averaged $44.8 \%$ of GDP, an increase of 15 percentage points on the low of 29.8\% of GDP in 2011 (see figure 2). Debt levels were uneven from one country to another, from less than 25\% of GDP at the end of 2019 in Paraguay and Peru to much higher figures in other countries: $89.4 \%$ in Argentina, $75.8 \%$ in Brazil and $61.3 \%$ in Costa Rica. The weight of the debt is evident not just in central governments, but in non-financial public enterprises (see box 1).

Figure 2 | Latin America (18 countries): central governments' gross public debt, 2000-2019 (Percentages of GDP)

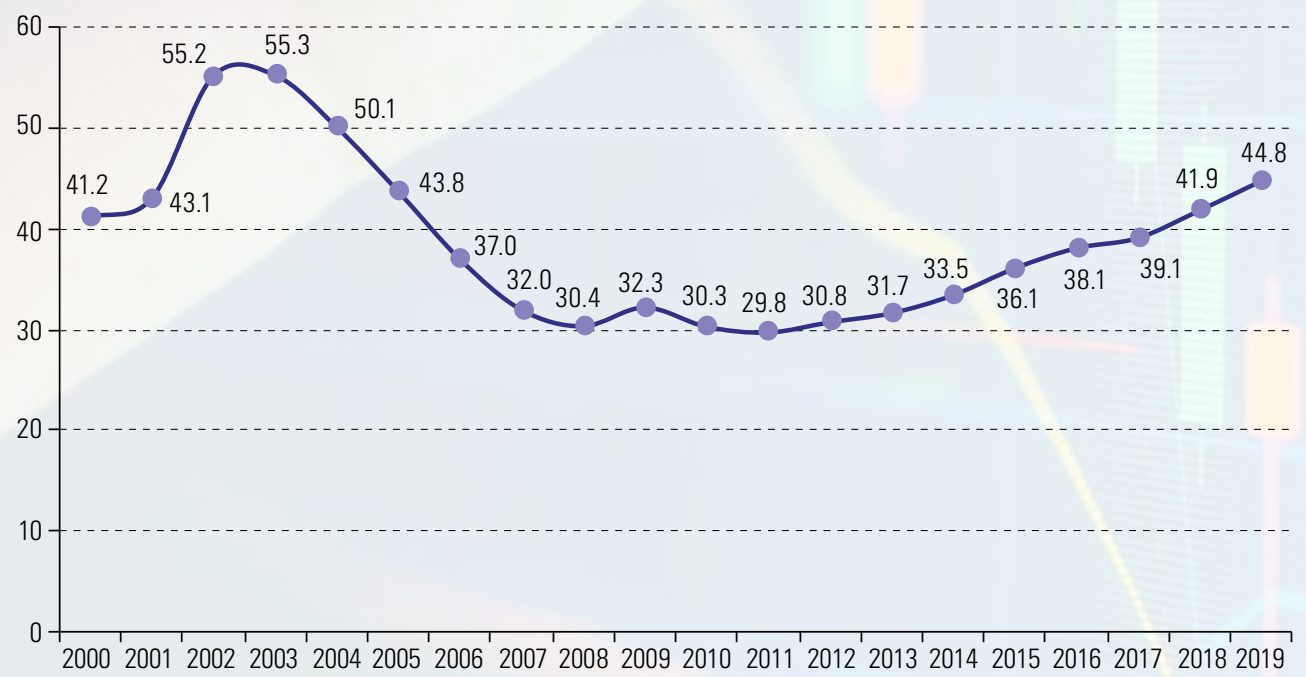

Source: Economic Commission for Latin America and the Caribbean (ECLAC), on the basis of official figures. 
Box 1 | Debt of non-financial public enterprises

Rising debt in Latin America and the Caribbean affects not only the central government, but also non-financial public enterprises, which increases the pressure on fiscal policy space. These companies are strategically important owing to their size, contribution to tax revenues and involvement in production and exports. The increase in debt affects, in particular, companies in the natural resource sectors hit by falling commodity prices and decreasing income and profitability.

On average in the region, $42 \%$ of non-financial public enterprises posted losses (net of fiscal transfers) in 2010-2016. The transfers required to cover these losses are expected to range from one third of a percentage point of GDP to one full percentage point of GDP. Recapitalizing non-financial public enterprises calls for similar or greater financing efforts, with the subsequent additional pressure on limited fiscal space. This situation gives rise to significant financial risks: the liabilities of non-financial public enterprises accounted for close to $9 \%$ of GDP, and in some cases between $17 \%$ of GDP and $20 \%$ of GDP (Pineda and Musacchio, 2020).

Source: Economic Commission for Latin America and the Caribbean (ECLAC).

Higher interest payments limited the resources available for development, as shown in the trend in governments' health spending and investment. Interest payments climbed from 1.7\% of GDP in 2010 to $2.6 \%$ of GDP in 2019 (see figure 3), while health spending rose much less (from 1.9\% of GDP in 2010 to $2.3 \%$ in 2018). Meanwhile, capital spending declined from $\mathbf{3 . 9 \%}$ of GDP to $3.2 \%$ of GDP, and acted as the variable of adjustment during the fiscal consolidation between 2016 and 2018. This situation is of particular concern in terms of the debt-service burden in Central American countries, as shown in box 2.

Figure 3 | Latin America (16 countries): central governments' interest payments, capital spending and health spending, 2010-2019a

(Percentages of GDP)

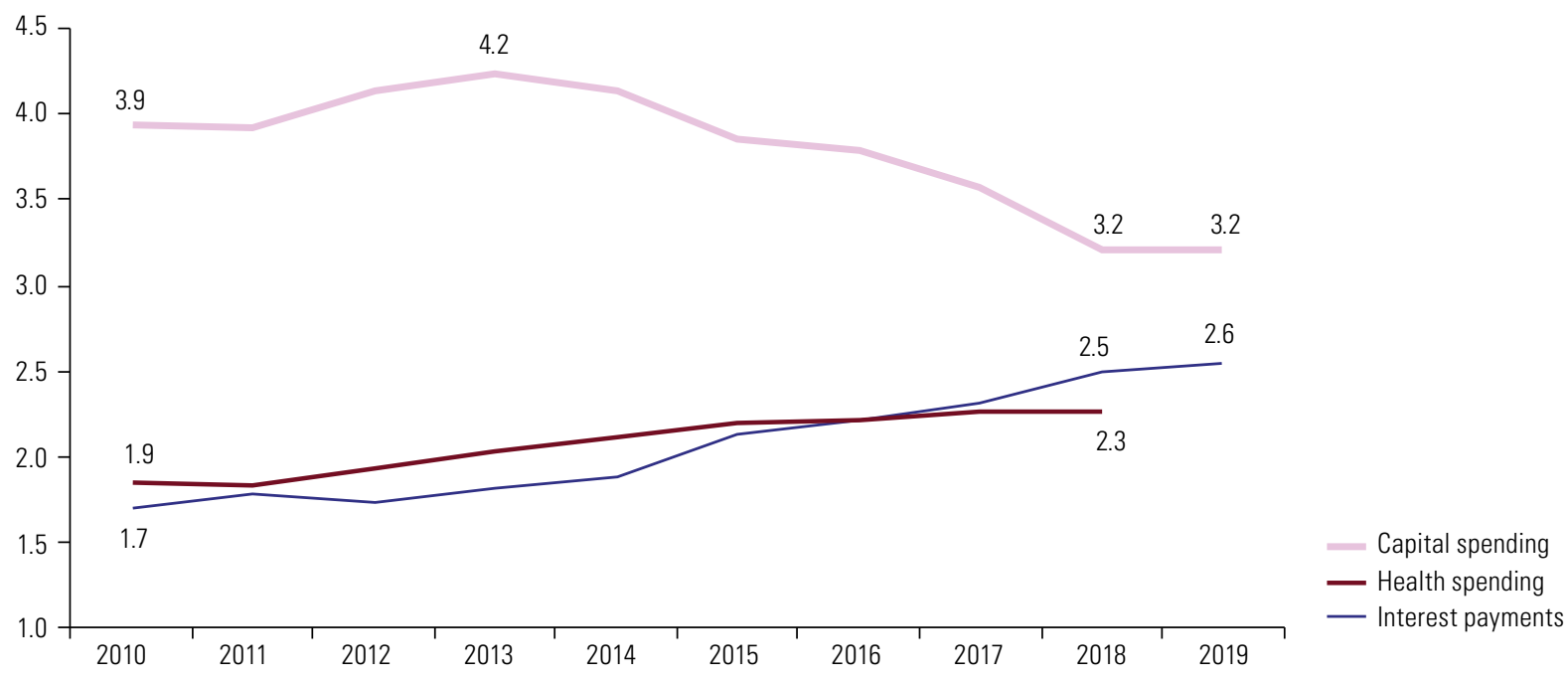

Source: Economic Commission for Latin America and the Caribbean (ECLAC), on the basis of official figures.

a Data on health spending available up to 2018. 


\section{Box 2 | Debt-service burden in Central America hinders public investment and social spending}

In the past decade, Central American countries have sought to reduce their debt burden through fiscal reforms (Costa Rica, Honduras) or by generating primary surpluses (El Salvador). However, for the countries included in the figure below, the gross public debt of central governments increased from $33.2 \%$ of GDP in 2010 to $44.0 \%$ of GDP in 2019 , on average. Meanwhile, interest payments rose from $1.8 \%$ of GDP to $2.5 \%$ of GDP.

Selected countries: central governments' gross public debt and interest payments, 2010 and 2019 (Percentages of GDP)
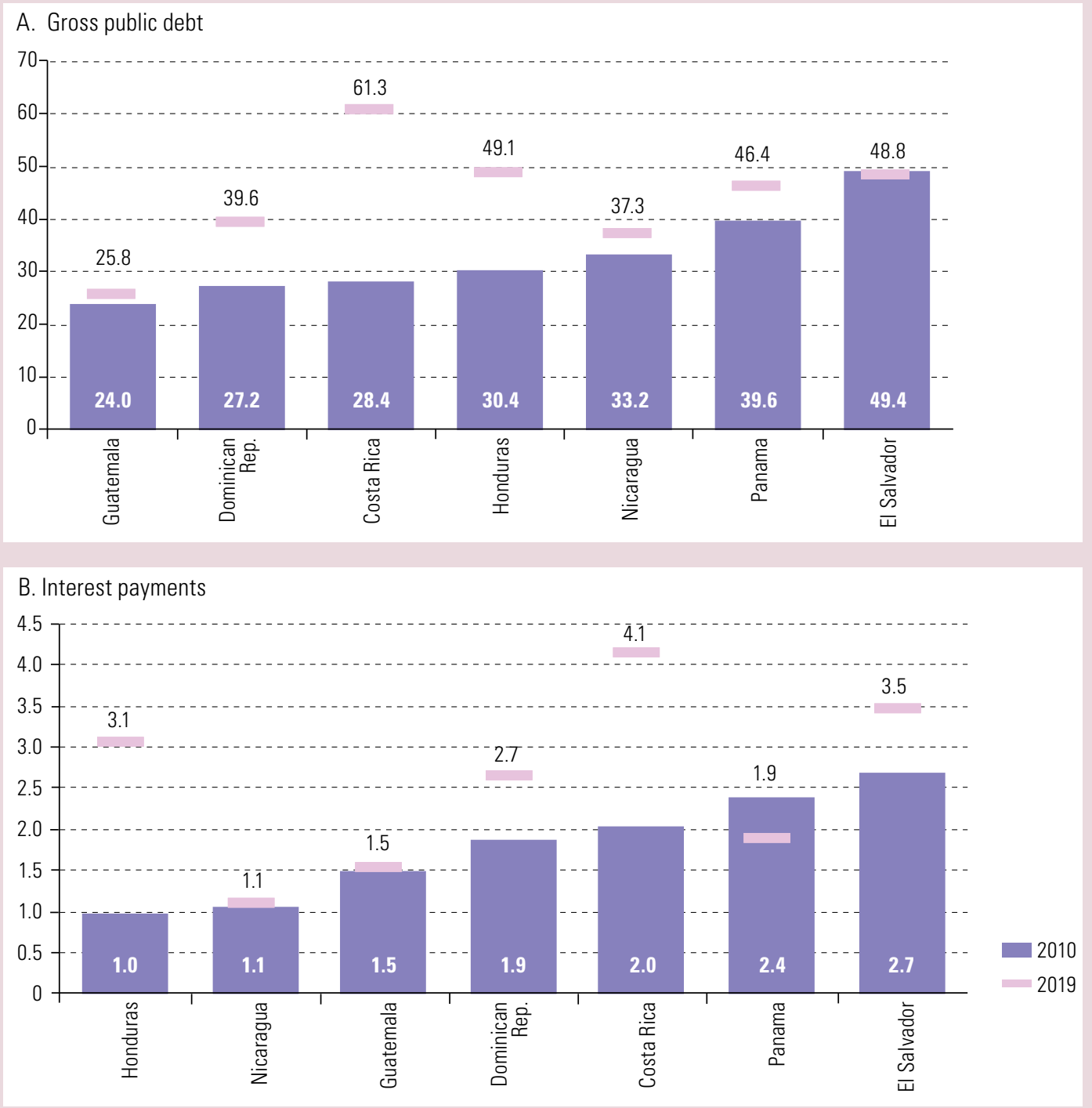

Seeking public debt sustainability, the Central American countries reduced capital spending to offset the increase in interest payments, which exceed spending on areas such as health, education and social protection. Central government health spending by the Dominican Republic (1.7\% of GDP), El Salvador (2.4\% of GDP), Guatemala (1.1\% of GDP), Honduras (2.4\% of GDP) and Panama (1.7\% of GDP) is lower than debt interest payments.

Using the same instruments as those employed in past crises would make it impossible to channel resources towards the humanitarian emergency, the recovery of economic activity and the maintenance of social stability. Hence, efforts to generate liquidity and fiscal space must serve as a framework to renew fiscal covenants and advance towards new social compacts.

Debt moratoriums negotiated with multilateral financial institutions would create the fiscal space and liquidity required to address the humanitarian and economic emergency without derailing efforts to make the subregion's debt sustainable.

Source: Economic Commission for Latin America and the Caribbean (ECLAC). 
Although most of the English-speaking countries of the Caribbean are considered middle-income, they are shackled by high public debt because of their constant need for financing to repair production structure damage from climate-related disasters. Accordingly, interest payments are a heavy burden on public spending. Although central governments have mostly achieved primary surpluses in the past decade (averaging $0.8 \%$ of GDP), they tend to run overall deficits, with an average of $2.5 \%$ of GDP and a maximum of $3.4 \%$ of GDP in 2013.

- The generation of primary surpluses hindered financing for public investment and social spending. Although the large primary surpluses resulted in a decrease in central governments' public debt from $72.8 \%$ of GDP in 2017 to $68.5 \%$ of GDP in 2019 (see figure 4), countries such as Barbados, Belize and Jamaica still have high levels of debt (122.6\%, 93.7\% and $87.4 \%$ of GDP, respectively) and therefore, high interest payments $(3.4 \%, 2.9 \%$ and $6.3 \%$ of GDP, respectively). This is in addition to their vulnerability to climate change and natural disasters that regularly destroy significant economic assets.

Figure 4 | The Caribbean (13 countries): central governments' gross public debt, 2000-2019 (Percentages of GDP)

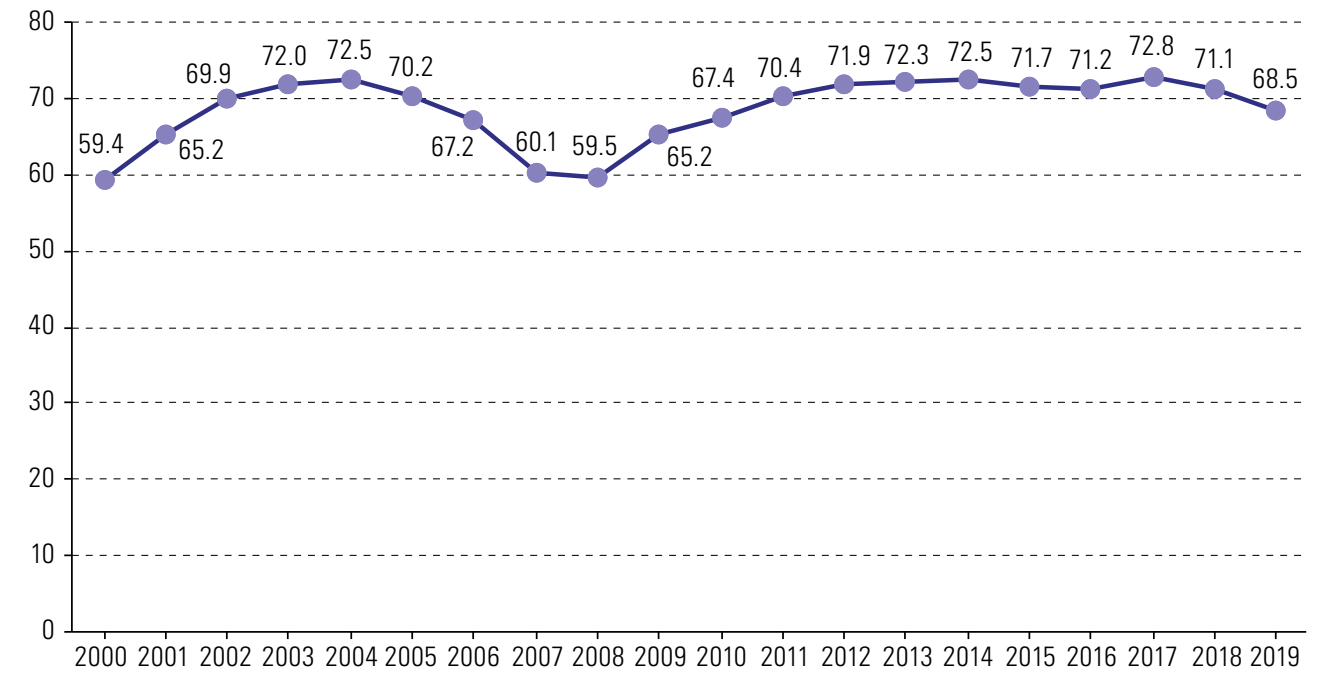

Source: Economic Commission for Latin America and the Caribbean (ECLAC), on the basis of official figures

- For Latin America and the Caribbean as a whole, fiscal space has been reduced by limited public revenue. In the past decade, the central governments of Latin America recorded total public revenue accounting for $18.2 \%$ of GDP, on average. This stagnation stemmed from the slowdown in economic activity, tax evasion, the decline in international commodity prices -especially in South America and Mexico-, tariff reductions amid trade liberalization, and increasing levels of tax revenue foregone through concessions for free zones and the maquila sector. In the current climate, public revenue will be even more affected by the sharp contraction in economic activity and depressed commodity prices.

\section{Monetary authorities' efforts to stimulate aggregate demand have resulted in historically low monetary policy rates, but with little effect thus far}

- Following the normalization of monetary policy by developed economies -especially the United States - at the end of 2013, and amid low inflation, the monetary authorities of Latin America and the Caribbean faced the dilemma of deciding whether to stimulate aggregate demand or avoid increasing macrofinancial instability. In 2019, the prolonged and widespread slowdowns in aggregate domestic demand in the region, especially in consumption and investment, the consequent decrease in inflation and reduced currency volatility allowed governments to adopt expansionary policies, with varying degrees of freedom depending on the exchange-rate regime.

Seeking to lower lending rates and boost domestic credit, monetary authorities' efforts focused on increasing liquidity by cutting monetary policy rates and expanding monetary aggregates. 
These efforts were complemented by interventions in foreign-exchange markets to mitigate exchange-rate pressures and external account deficits. Although monetary policy rates were historically low at the end of 2019 , lending rates remained broadly stable and credit to the private sector contracted in real terms (see figure 5). Both these trends reflect how difficult it is for monetary policy to soften the impact of low growth on credit risk and agents' willingness to increase their consumption and investment.

Figure 5 | Latin America and the Caribbean (selected countries): real domestic credit to the private sector, average year-on-year rates, first quarter of 2016-first quarter of 2020 (Percentages)

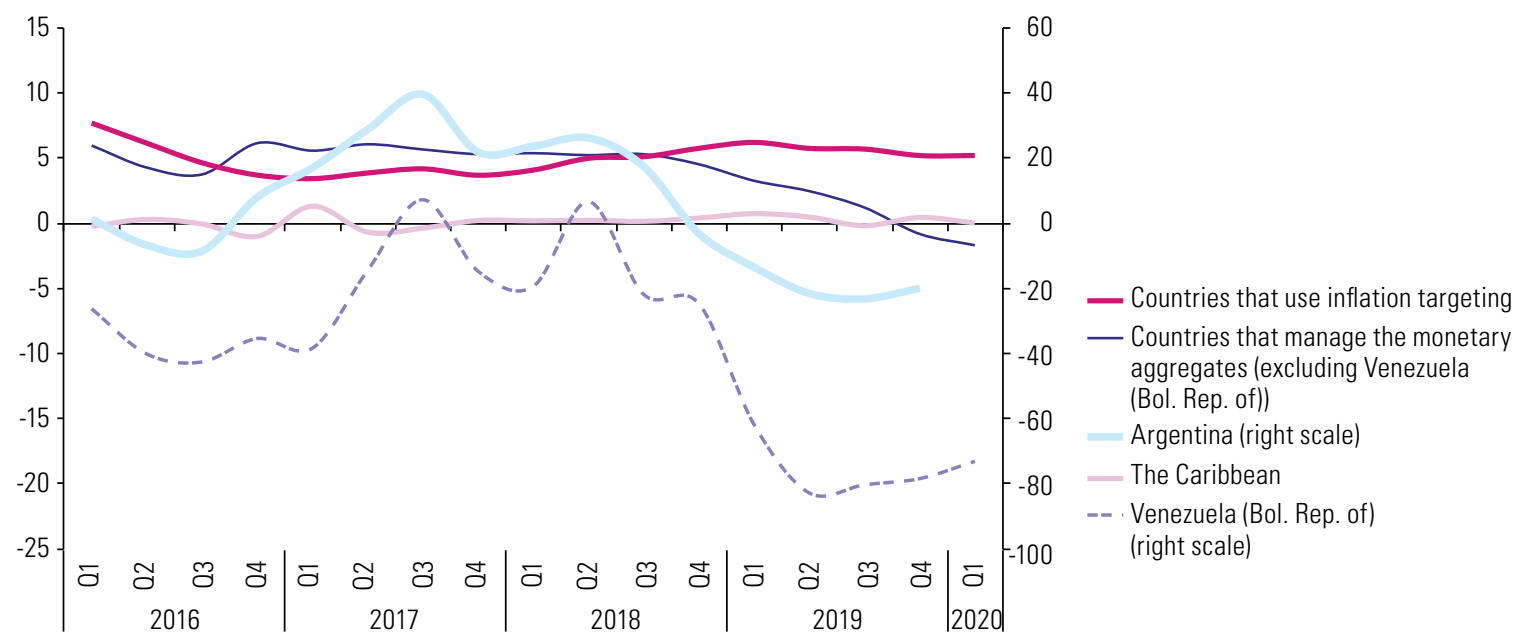

Source: Economic Commission for Latin America and the Caribbean (ECLAC), on the basis of official figures

The high level of private sector debt (households and private non-financial corporations) has conditioned monetary policy and, possibly, its effectiveness. The increase in debt along with decreasing profitability affects the non-financial corporate sector as a whole and causes concern about the effects of the current crisis on companies. Between December 2001 and September 2019, private debt in Argentina, Brazil, Chile, Colombia and Mexico rose from US\$ 688 million to US\$ 2.445 billion (see figure 6). Moreover, between $47 \%$ and $62 \%$ of 2,241 companies in the region across 34 sectors of economic activity saw their profitability decline between 2010 and 2016.

Figure 6 | Latin America (five countries ${ }^{\mathrm{a}}$ ): non-financial private sector debt, quarterly data, 2001-2019 (Millions of dollars)

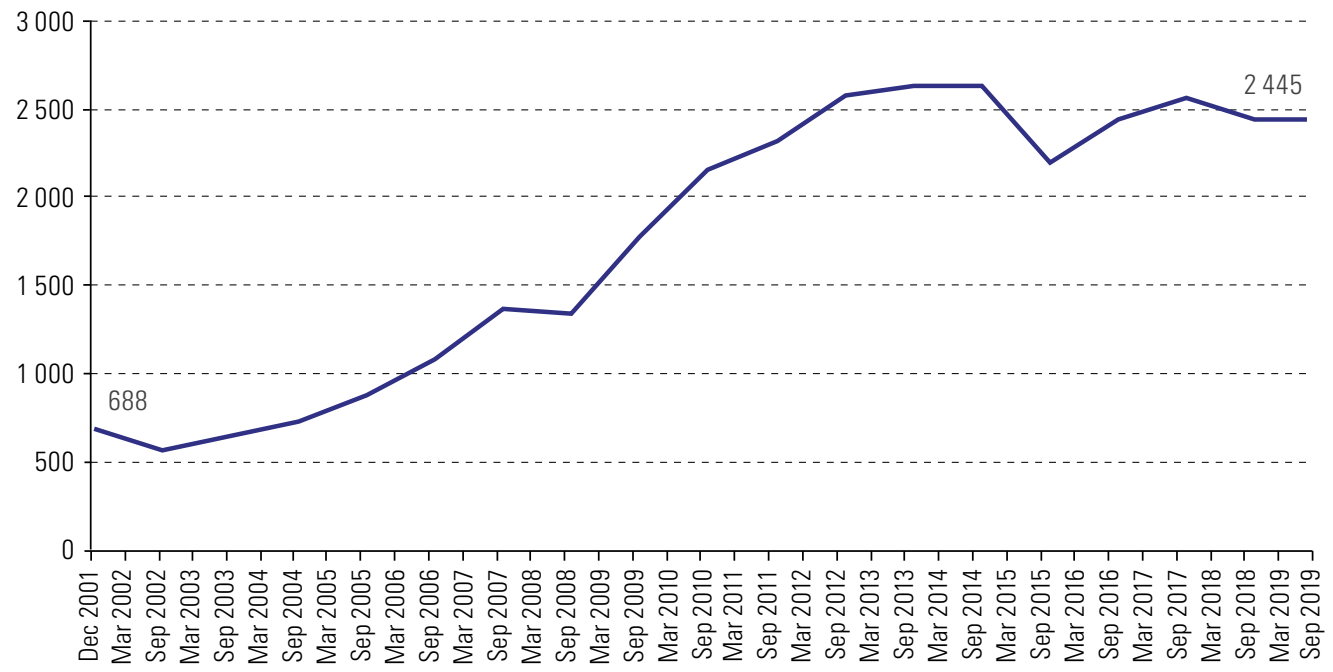

Source: Economic Commission for Latin America and the Caribbean (ECLAC), on the basis of data from the Bank for International Settlements (BIS), "Debt securities statistics", 2020 [online] https://www.bis.org/statistics/secstats.htm.

a Argentina, Brazil, Chile, Colombia and Mexico. 


\section{B. The pandemic will lead to the most severe contraction in economic activity in the region's history}

- The pandemic is affecting the economies of Latin America and the Caribbean through external and domestic factors whose combined impact will lead to the most severe contraction in economic activity that the region has experienced since records began in 1900.

\section{The external impact}

- The decline in the world's gross output in $\mathbf{2 0 2 0}$ will be the largest in decades. Global GDP is expected to shrink by around $2 \%$, with a larger contraction in developed economies than in emerging economies.

- On average, projections point to a decline of almost $\mathbf{4} \%$ for the United States (compared to a growth forecast of $1.9 \%$ in December 2019), less than $\mathbf{2 \%}$ growth for China $(5.8 \%$ forecast in December), a decline of almost $\mathbf{6} \%$ for the eurozone (1.2\% growth forecast in December) and a contraction of more than $\mathbf{4} \%$ for Japan (see table 1).

Table 1 | Selected regions and countries: GDP growth rates for 2013-2019 and projected rates for 2020 (Percentages)

\begin{tabular}{lrrrrrrrr}
\hline & $\mathbf{2 0 1 3}$ & $\mathbf{2 0 1 4}$ & $\mathbf{2 0 1 5}$ & $\mathbf{2 0 1 6}$ & $\mathbf{2 0 1 7}$ & $\mathbf{2 0 1 8}$ & $\mathbf{2 0 1 9}$ & $\mathbf{2 0 2 0}$ \\
World & $\mathbf{2 . 6}$ & $\mathbf{2 . 8}$ & $\mathbf{2 . 8}$ & $\mathbf{2 . 6}$ & $\mathbf{3 . 2}$ & $\mathbf{3 . 1}$ & $\mathbf{2 . 4}$ & $\mathbf{- 2 . 0}$ \\
\hline United States & 1.8 & 2.5 & 2.9 & 1.6 & 2.4 & 2.9 & 2.3 & -3.8 \\
\hline Japan & 2.0 & 0.4 & 1.3 & 0.6 & 2.0 & 0.8 & 0.7 & -4.2 \\
\hline Eurozone & -0.3 & 1.4 & 2.1 & 1.9 & 2.5 & 1.9 & 1.2 & -5.7 \\
\hline China & 7.8 & 7.3 & 6.9 & 6.7 & 6.9 & 6.6 & 6.1 & 1.8 \\
\hline India & 6.4 & 7.4 & 8.0 & 8.2 & 7.2 & 6.8 & 5.8 & 3.4 \\
\hline
\end{tabular}

Source: Economic Commission for Latin America and the Caribbean (ECLAC), on the basis of Institute of International Finance (IIF), Capital Flows Report: Sudden Stop in Emerging Markets, 9 April 2020; and data from Bloomberg.

The volume of world trade has collapsed: the World Trade Organization (WTO) estimates a fall of between $13 \%$ and $32 \%$ in 2020 .

- The volume of global trade in goods was following a downward trend before the pandemic. In 2019 , it declined by $0.4 \%$, the first drop since the global financial crisis (see figure 7). This was largely the result of the build-up of trade barriers since early 2018 (mainly between the United States and China) and its effect on global value chains. The outlook improved in January 2020 following the "phase one" agreement between China and the United States, but the pandemic put an end to that short-lived optimism.

- In addition to disruption of value chains, once China starts resuming production, it will have problems in exporting to countries that are experiencing the pandemic with a time lag with respect to its own timeline. Thus, one of the main players in world trade will see reduced demand for its exports, amplifying the negative impact on the global volume of trade.

The drop in global economic activity, and particularly in the United States, China and Europe, is hurting trade volumes and prices in Latin America and the Caribbean, especially for commodities. Some key production sectors in countries of the region form part of global value chains in which the United States and China are fundamental. In addition, Mexico and Central America are exposed to contractions in the United States economy through reduced remittances from migrants; in the case of Mexico, this is compounded by the fall in oil prices.

In view of the new economic outlook for the region's key trading partners and the steepening fall in export prices, the projections presented in the first issue of this Special Report are revised below. The new estimate indicates that the value of the region's exports could fall by nearly $\mathbf{1 5 \%}$, with an $8.8 \%$ drop in prices and a $6 \%$ decline in volume, essentially owing to a sharper contraction in global demand (see table 2). 
Figure 7 | Year-on-year change in the volume of global goods trade (Percentages, on the basis of a seasonally adjusted index)

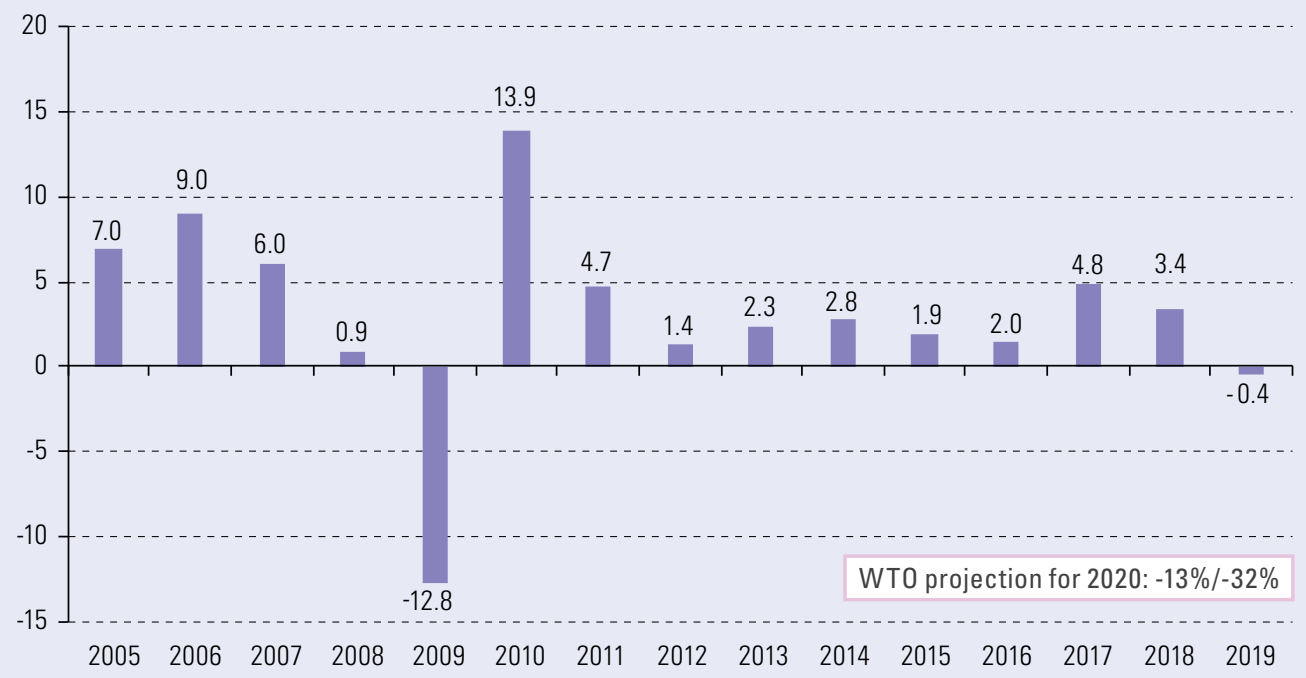

Source: Economic Commission for Latin America and the Caribbean (ECLAC), on the basis of Netherlands Bureau of Economic Policy Analysis (CPB), World Trade Monitor [online database] https://www.cpb.nl/en/worldtrademonitor. World Trade Organization (WTO), "Trade forecast press conference", 8 April 2020 [online] https://www.wto.org/english/news_e/spra_e/spra303_e.htm.

Table 2 | Latin America and the Caribbean: impact of COVID-19 on goods exports by subregions and major exporting countries, forecast for 2020

(Percentage change)

\begin{tabular}{|c|c|c|c|c|c|c|}
\hline \multirow{2}{*}{ Region/Subregion/Country } & \multicolumn{3}{|c|}{ First COVID-19 Special Report ${ }^{\mathrm{a}}$} & \multicolumn{3}{|c|}{ Updated projections $^{b}$} \\
\hline & Volume & Price & Value & Volume & Price & Value \\
\hline Latin America and the Caribbean & -2.5 & -8.2 & -10.7 & -6.0 & -8.8 & -14.8 \\
\hline Oil exporters & -1.8 & -14.1 & -15.9 & -4.7 & -14.6 & -19.2 \\
\hline Mineral exporters & -3.0 & -8.9 & -12.0 & -7.4 & -9.3 & -16.7 \\
\hline $\begin{array}{l}\text { Exporters of agro-industry } \\
\text { products }\end{array}$ & -2.4 & -2.5 & -5.0 & -6.2 & -4.0 & -10.2 \\
\hline South America & -2.8 & -11.0 & -13.8 & -6.0 & -11.6 & -17.6 \\
\hline Brazil & -3.7 & -7.5 & -11.2 & -7.0 & -8.1 & -15.1 \\
\hline Mexico & -2.2 & -5.2 & -7.4 & -6.0 & -5.7 & -11.6 \\
\hline Central America & -1.3 & -2.7 & -4.0 & -4.9 & -5.3 & -10.3 \\
\hline Caribbean countries & -2.0 & -7.2 & -9.3 & -6.2 & -7.7 & -13.9 \\
\hline
\end{tabular}

Source: Economic Commission for Latin America and the Caribbean (ECLAC).

a The following growth rates are assumed for 2020: 1.0\% (world), 1.0\% (United States), 0.3\% (Japan), 0.5\% (European Union, 27 countries), 3.0\% (China) and $-1.8 \%$ (Latin America and the Caribbean), plus an average reduction of 16\% in the region's commodity export basket.

b The following growth rates are assumed for 2020: -2.0\% (world), -3.8\% (United States), -4.2\% (Japan), -5.7\% (European Union, 27 countries), 1.8\% (China) and $-5.3 \%$ (Latin America and the Caribbean), plus an average reduction of $18 \%$ in the region's commodity export basket.

- On average, the low prices are expected to persist, even for products that had not seen declines. For example, in recent weeks the market prices of agricultural products that had not fallen as much as oil and metals have begun to slide, due to shrinking demand. Soybean, corn and wheat prices have fallen by up to $4 \%$, and futures for the second quarter have started to tumble. Similar patterns can be seen in beef and chicken, with average drops of $6 \%$ over the past two months. In the case of oil -the region's main export product - the sharp drop in demand, estimated at 30\%, was too large to be offset by the latest agreement of the Organization of Petroleum Exporting Countries (OPEC), which cuts the output of OPEC member countries by $20 \%$ (to 9.7 million barrels per day).

- The greatest impact will be felt by the countries of South America, which specialize in the export of commodities and are therefore more vulnerable to a decline in their prices.

- Regional exports to China are expected to fall the most in $\mathbf{2 0 2 0}(24.4 \%)$ (see table 3). This is likely to affect chiefly products with forward linkages in value chains in China (iron ore, copper ore, zinc, aluminium, soybeans, soybean oil, among others). The most exposed countries are Argentina, Brazil, Chile and Peru, the region's largest exporters of such products to China. 
Table 3 | Latin America and the Caribbean: impact of COVID-19 on goods exports to the world and to selected trading partners, forecast for 2020

(Percentage change)

\begin{tabular}{|c|c|c|c|}
\hline Destinations & $\begin{array}{l}\text { Projections from first } \\
\text { COVID-19 Special Report }\end{array}$ & $\begin{array}{l}\text { Updated } \\
\text { projections }^{\mathrm{b}}\end{array}$ & Most affected sectors and countries \\
\hline World & -10.7 & -14.8 & \\
\hline \multirow[t]{2}{*}{ China } & -21.7 & -24.4 & $\begin{array}{l}\text { Agricultural and agro-industry } \\
\text { products (Argentina, Brazil, } \\
\text { Uruguay, Paraguay); }\end{array}$ \\
\hline & & & Mining products (Chile and Peru) \\
\hline United States & -7.1 & -11.6 & Manufactures (Mexico, Costa Rica) \\
\hline European Union & -8.9 & -16.1 & $\begin{array}{l}\text { Mining products (Chile, Colombia, } \\
\text { Ecuador, Peru); Agricultural and } \\
\text { agro-industry products (Argentina, } \\
\text { Brazil, Chile, Peru) }\end{array}$ \\
\hline $\begin{array}{l}\text { Latin America and } \\
\text { the Caribbean }\end{array}$ & -10.7 & -14.5 & Low- and medium-tech manufactures \\
\hline
\end{tabular}

Source: Economic Commission for Latin America and the Caribbean (ECLAC).

a The following growth rates are assumed for 2020: 1.0\% (world), 1.0\% (United States), 0.3\% (Japan), 0.5\% (European Union, 27 countries), 3.0\% (China) and $-1.8 \%$ (Latin America and the Caribbean), plus an average reduction of 16\% in the region's commodity export basket.

b The following growth rates are assumed for 2020: $-2.0 \%$ (world), -3.8\% (United States), -4.2\% (Japan), -5.7\% (European Union, 27 countries), 1.8\% (China) and $-5.3 \%$ (Latin America and the Caribbean), plus an average reduction of 18\% in the region's commodity export basket.

- The deterioration in global financial conditions is as bad as - and in some indicators worse than - in the 2008-2009 global financial crisis.

Volatility has increased to record levels, there have been massive capital outflows from emerging markets, most currencies have depreciated against the dollar and there have been sharp increases in sovereign risk, except in countries that are considered safe havens to which investors "flee" in search of security, where sovereign risk has hit record lows. Stock markets around the world have plummeted, reflecting concerns about how the pandemic will affect companies' financials.

- The fact that financial markets have been severely affected by the global pandemic is also a result of financial vulnerabilities that had been building up for a long time. The volume of debt has been growing faster than global income, and has reached all-time highs. In the fourth quarter of 2019, the global debt stock exceeded US\$255 trillion, more than $322 \%$ of global GDP (IIF, 2020b).

The increase in debt was accompanied by laxer borrowing requirements and greater appetite for risk among investors seeking higher returns. While debt has risen across all sectors (households, non-financial corporate sector, government and financial sector), what is extremely concerning now is that much of the debt accumulated since the global financial crisis has been incurred by the non-financial corporate sector, where disruption of supply chains and falls in global growth mean lower profitability and greater difficulty servicing debt. The recession makes it harder for corporate borrowers to make profits and repay debt and this situation is exacerbated by the rising costs of borrowing and the disruptions to access to financing.

In Latin America, the reduced availability of financing flows for emerging economies is translating into a slowdown in capital flows from abroad (a decrease of almost US $\$ 80$ billion compared to 2019) and net portfolio and other investment outflows among non-residents (see figure 8) (IIF, 2020c).

- Remittance flows to Latin America and the Caribbean could contract by $10 \%-15 \%$ in 2020 and could take 4-8 years to return to the levels seen in 2019. In several countries of the region, these flows make a very significant contribution to economic activity (see figure 9). In Haiti they represented more than 30\% of GDP; in El Salvador and Honduras they contributed around 20\%, and in Guatemala, Jamaica and Nicaragua over 10\%. Between $80 \%$ and $90 \%$ of remittances are used to cover basic needs of the recipient households (food, health and housing). The contraction will therefore have a major impact on consumption and on poverty. 
Figure 8 || Capital flows from non-residents to Latin America, 2000-2020 (Billions of dollars)

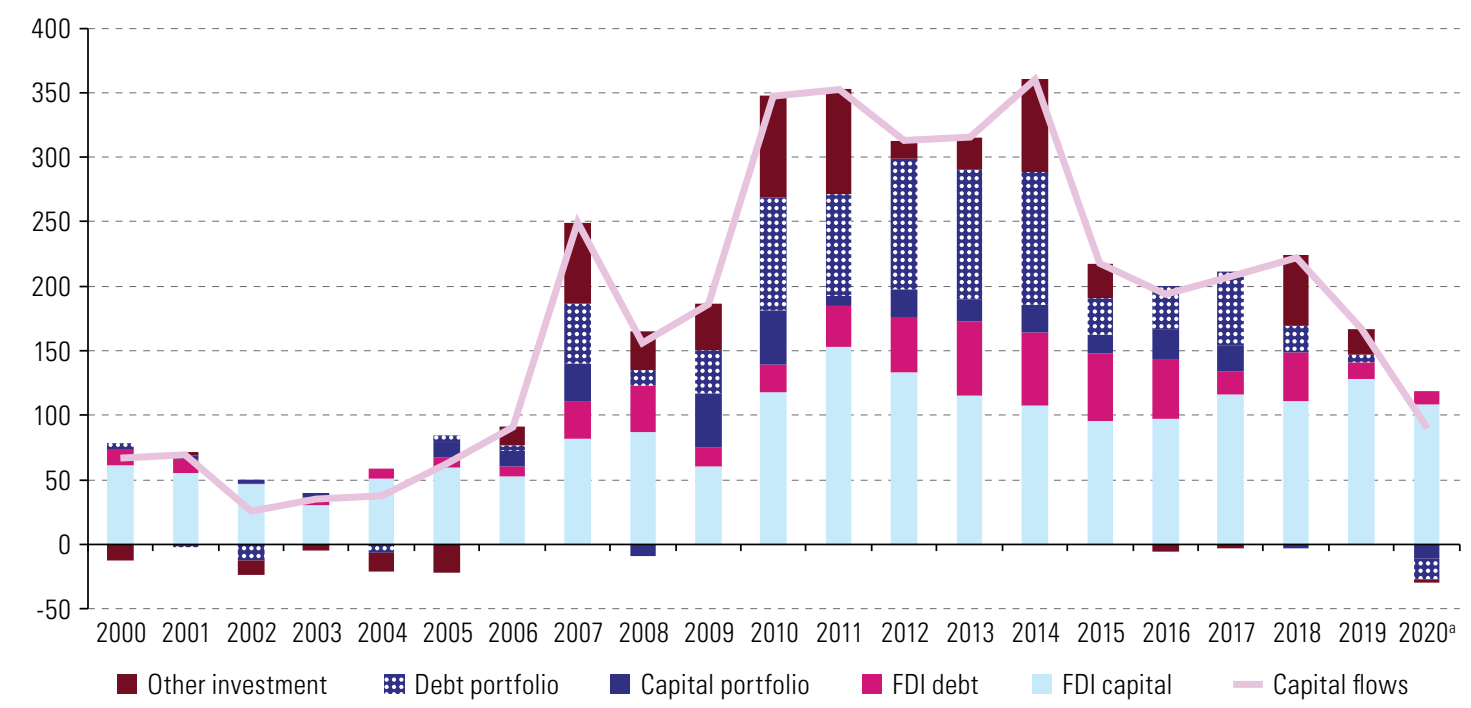

Source: Institute of International Finance (IIF)

a Projection.

Figure 9 | Latin America and the Caribbean: family remittance flows as a percentage of GDP, 2018 (Percentages)

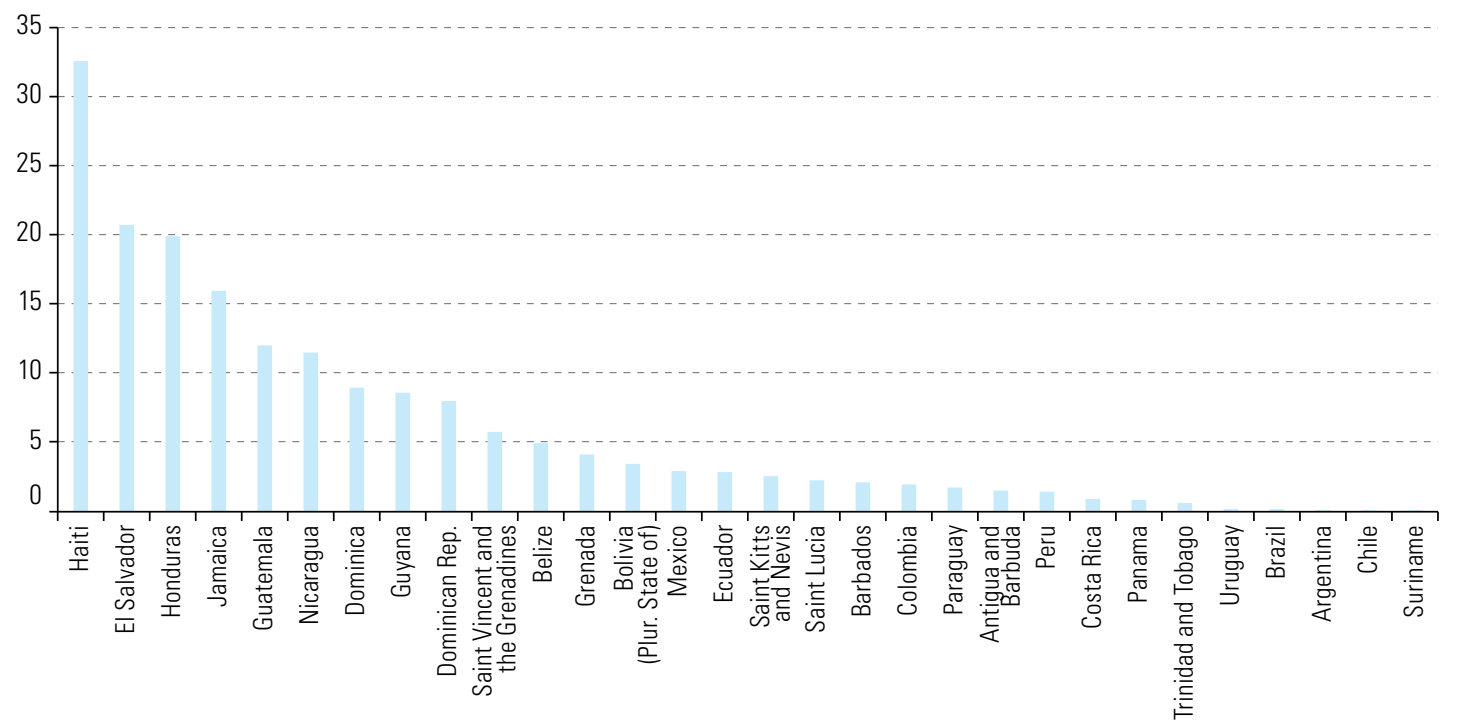

Source: Economic Commission for Latin America and the Caribbean (ECLAC), on the basis of World Bank, World Development Indicators (WDI) [online database] http://datatopics.worldbank.org/world-development-indicators/.

In the main destination country for migrants in the region (the United States), the health crisis is affecting sectors where migrants are traditionally employed, such as construction, restaurants and hotels. In 2018, 28.7\% of migrants from the countries of the region were employed in services and $20.6 \%$ in construction and maintenance (United States Bureau of the Census, 2018). The impact of the crisis on remittances could be mitigated by the direct support (transfers) received by migrants in destination countries and by the recipient families in the communities of origin. The crisis has also highlighted the contributions made by the immigrant workforce in sectors such as food production and health services in countries where migrants have a large presence.

- Tourism is one of the worst affected sectors and its recovery will depend how and when borders are opened across the world. Tourist arrivals globally are expected to fall by between $20 \%$ and $30 \%$ in 2020, a much larger drop than in 2009 (4\%) (UNWTO, 2020). In a scenario with a 
$30 \%$ drop in tourism revenues in 2020, GDP would fall by 2.5, 0.8 and 0.3 percentage points in the Caribbean, Mexico and Central America, and South America, respectively. The knock-on effects on employment, household incomes and government revenues would be greatest in the Caribbean, where the sector employs some 2.4 million people and accounts for $15.5 \%$ of GDP (see figure 10). The effects of the decline in tourism will be felt in particular by micro- and small enterprises, which represent a huge proportion of the hotel and restaurant sector: $99 \%$ of enterprises and $77 \%$ of employment (ECLAC, 2020).

Figure 10 | Latin America and the Caribbean: contribution of tourism to GDP and employment, 2018 (Percentages)

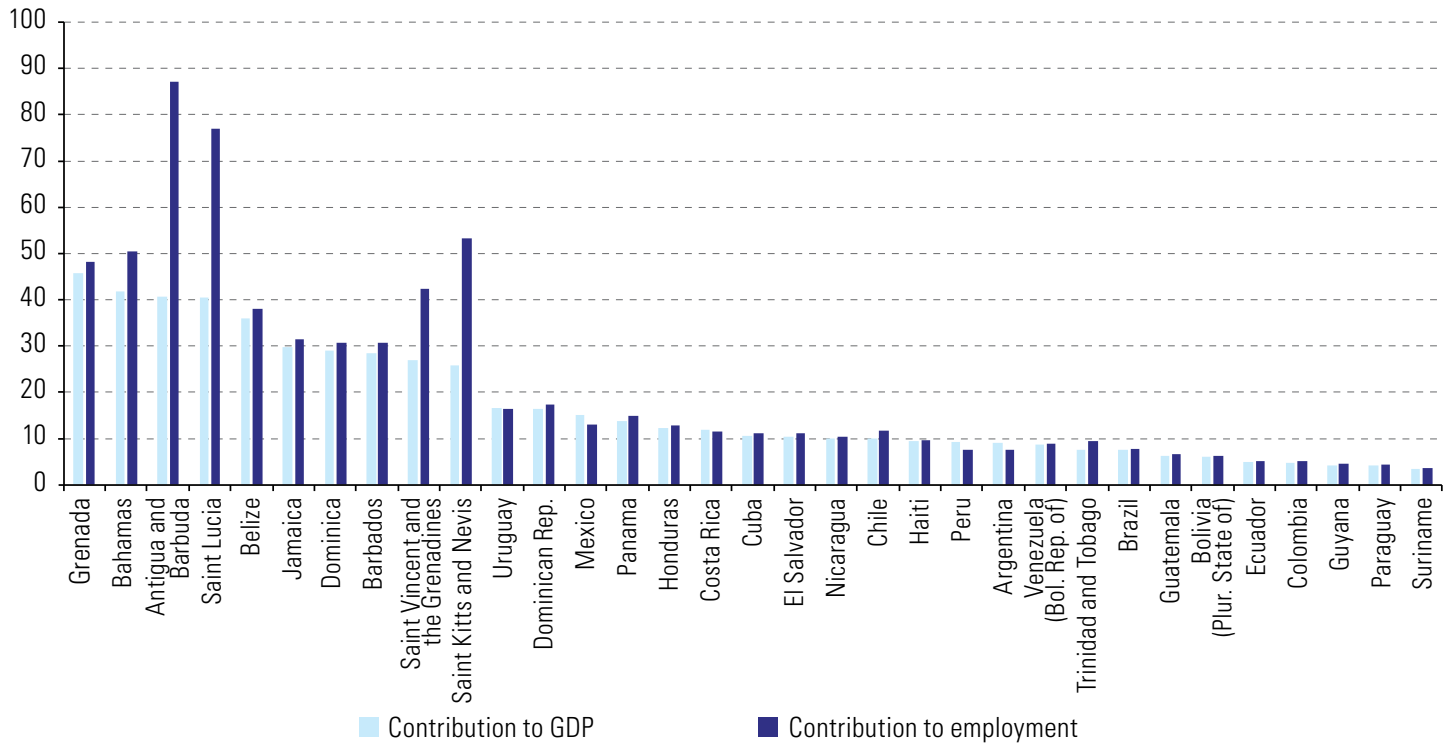

Source: Economic Commission for Latin America and the Caribbean (ECLAC), on the basis of data from the World Travel and Tourism Council (WTTC).

\section{The domestic impact}

Major domestic impacts are adding the external effects, as health policies to contain the spread of the pandemic bring production and economic activity to a halt. In the absence of treatments and vaccines for the virus, efforts to control the epidemic are focused on restricting the movement of people, which affects production activity to different extents, depending on the sector in question. Quarantines and social isolation have led to slumps in activities such as aviation, tourism, commerce and free zones.

- Companies, regardless of their size, are facing substantial falls in revenue, difficulties in obtaining credit and an increased likelihood of insolvency.

- In addition, severe impacts on people's working conditions and on employment or income are leading in turn to declines in countries' aggregate demand and increases in poverty.

- Sectors may be divided into three groups, according to the degree to which they are likely to be affected by containment measures. These groups represent very different proportions of GDP in each country, which are estimated here directly without considering secondary or intersectoral impacts (see table 4):

(i) the least affected: agriculture, livestock, hunting, forestry and fishing.

(ii) the moderately affected: mining and quarrying, manufacturing industries, electricity, gas and water supply, construction, financial intermediation, real estate, business and rental services, civil service, social and personal services.

(iii) the most affected: wholesale and retail, repair of goods, hotels and restaurants, transport, storage and communications, services in general. 
Table 4 Latin America: proportion of GDP of economic sectors by intensity of COVID-19 impact (Percentages)

\begin{tabular}{|c|c|c|c|c|}
\hline & \multicolumn{4}{|c|}{ Sectors } \\
\hline & Least affected & Moderately affected & Most affected & Total \\
\hline Argentina & 10.5 & 63.6 & 25.9 & 100.0 \\
\hline $\begin{array}{l}\text { Bolivia (Plurinational } \\
\text { State of) }\end{array}$ & 14.4 & 65.0 & 20.6 & 100.0 \\
\hline Brazil & 7.9 & 75.8 & 16.4 & 100.0 \\
\hline Chile & 3.7 & 75.0 & 21.4 & 100.0 \\
\hline Colombia & 6.8 & 71.0 & 22.2 & 100.0 \\
\hline Costa Rica & 5.3 & 71.7 & 23.0 & 100.0 \\
\hline Ecuador & 9.9 & 66.5 & 23.6 & 100.0 \\
\hline Guatemala & 10.5 & 59.1 & 30.4 & 100.0 \\
\hline El Salvador & 10.4 & 65.5 & 24.1 & 100.0 \\
\hline Honduras & 12.1 & 63.6 & 24.3 & 100.0 \\
\hline Mexico & 3.4 & 65.9 & 30.7 & 100.0 \\
\hline Nicaragua & 16.2 & 59.9 & 23.9 & 100.0 \\
\hline Panama & 2.4 & 62.1 & 35.5 & 100.0 \\
\hline Peru & 6.3 & 67.4 & 26.3 & 100.0 \\
\hline Paraguay & 12.1 & 87.9 & 0.0 & 100.0 \\
\hline Uruguay & 6.7 & 54.8 & 38.5 & 100.0 \\
\hline $\begin{array}{l}\text { Venezuela (Bolivarian } \\
\text { Republic of) }\end{array}$ & 5.1 & 72.5 & 22.4 & 100.0 \\
\hline
\end{tabular}

Source: Economic Commission for Latin America and the Caribbean (ECLAC), on the basis of official figures.

Note: Calculated on the basis of the level of GDP in real terms at 2019 prices.

- This grouping of sectors, which will be used later to estimate the effects of the pandemic on GDP in 2020, has various dimensions in terms of pace of growth, production structure and technological intensity, which will be analysed in subsequent issues of this Special Report.

\section{Policy responses to tackle the economic and social effects of the pandemic}

- The countries of Latin America and the Caribbean were quick to implement significant measures in response to the initial stage of the crisis, adopting a broad range of economic policies to mitigate its social and economic effects. These measures aim to increase public resources for the health sector, protect households (especially the most vulnerable ones), safeguard production capacity and employment, stave off a liquidity crisis and prevent the collapse of the economic system (see table 5).

- The scale of the efforts on the fiscal policy front surpasses the stimulus measures implemented during the global financial crisis. There are a few noteworthy examples in the region. Peru announced measures costing just over $7 \%$ of GDP, complemented by State credit guarantees of up to $4 \%$ of GDP, while Chile announced initiatives for the equivalent of $5.5 \%$ of GDP with added guarantees for loans that could represent as much as $10 \%$ of GDP. 
Table 5 | Measures announced by countries to tackle the pandemic

The region's countries have taken immediate measures to contain the virus and protect the workforce and household income

- Travel restrictions and monitoring of travellers from areas affected by COVID-19.

- Flight bans (to and from specific countries) and border closures.

- Distance learning and homeschooling (with asymmetries in connectivity).

- Social distancing, with the closure of restaurants, bars, cinemas, the encouragement of teleworking and reduced office hours.

- Strengthening health sector capacity: health infrastructure (beds, mobile hospitals, medical supplies) across the region is fragmented and insufficient, counting just over 2 beds per 1000 people.
- Total or partial quarantine with working arrangements including legal measures for teleworking, reduced working hours, introduction of flexible hours, advance leave and protection against dismissal.

- Protection of the workforce and income in the form of wage support to offset loss of income through advance payments, wage subsidies, strengthening of unemployment insurance and the suspension or reduction of payments for water, gas and electricity services or towards private pension funds.

- Social protection to reduce the social impact on people with the lowest incomes through subsidies, cash transfers or advance payments, social programmes and social protection mechanisms.

- Special financial support for SMEs and other companies and the informal sector, by renegotiating and improving conditions for bank loans.

Monetary, fiscal and social measures to avoid the collapse of the economic system

- Monetary and financial measures to preserve bank liquidity, support commerce and address public and private debt; lowering of central bank interest rates and opening of special credit lines, granting of additional loans, extension of repayment terms for consumer and corporate loans or extension of mortgage terms.

- Fiscal measures include flexibility to redirect public budgets, introduce tax relief measures, defer tax returns or apply tax exemptions for certain sectors; finance ministers should reorganize budgets and seek additional financing to channel resources towards urgent short-term measures. Argentina, the Bahamas, Barbados, Belize, Brazil, Chile, Colombia, Guatemala, Honduras, Jamaica, Paraguay, Peru, Trinidad and Tobago and Uruguay have implemented fiscal packages ranging from $0.6 \%$ of GDP to more than 10\% of GDP when State loan guarantees are included.

- Measures to preserve production capacity and to create the conditions to revive economic activity through liquidity mechanisms for companies, particularly SMEs.

- Measures to expand social protection systems to cover underemployed or own-account workers, young people, women, children and older persons.

Source: Economic Commission for Latin America and the Caribbean (ECLAC).

At the outset, countries took steps to release resources quickly through the widespread use of budget reallocations to strengthen health systems and expand social safety nets by means of transfers to offset income losses of formal-sector and informal employees. These initiatives have often been accompanied by tax relief measures aimed at reducing pressure on companies' cash flows. In addition, credit guarantees were extended to ensure that companies, especially SMEs, have access to liquidity provided that they maintain employment levels.

- Monetary authorities have taken measures to increase liquidity through the use of "traditional" instruments and have lowered monetary policy interest rates (see figure 11) and legal reserve requirements. They have announced assistance to financial institutions, especially through short-term markets, to avoid mismatches and prevent illiquidity from turning into insolvency. Interventions on the foreign-exchange market have also been stepped up, not to reverse currency depreciations that have already occurred, but to mitigate volatility.

- The fiscal stimulus measures taken in response to the humanitarian and economic crisis will substantially widen fiscal deficits and increase debt levels in many countries. Therefore, fiscal covenants will have to be renewed in many countries of the region to enable them to face future adjustments and minimize financial risks. 
Figure 11 | Latin America (selected countries): monetary policy interest rate in countries that use this as the key policy instrument, January 2016-April 2020

(Percentages)

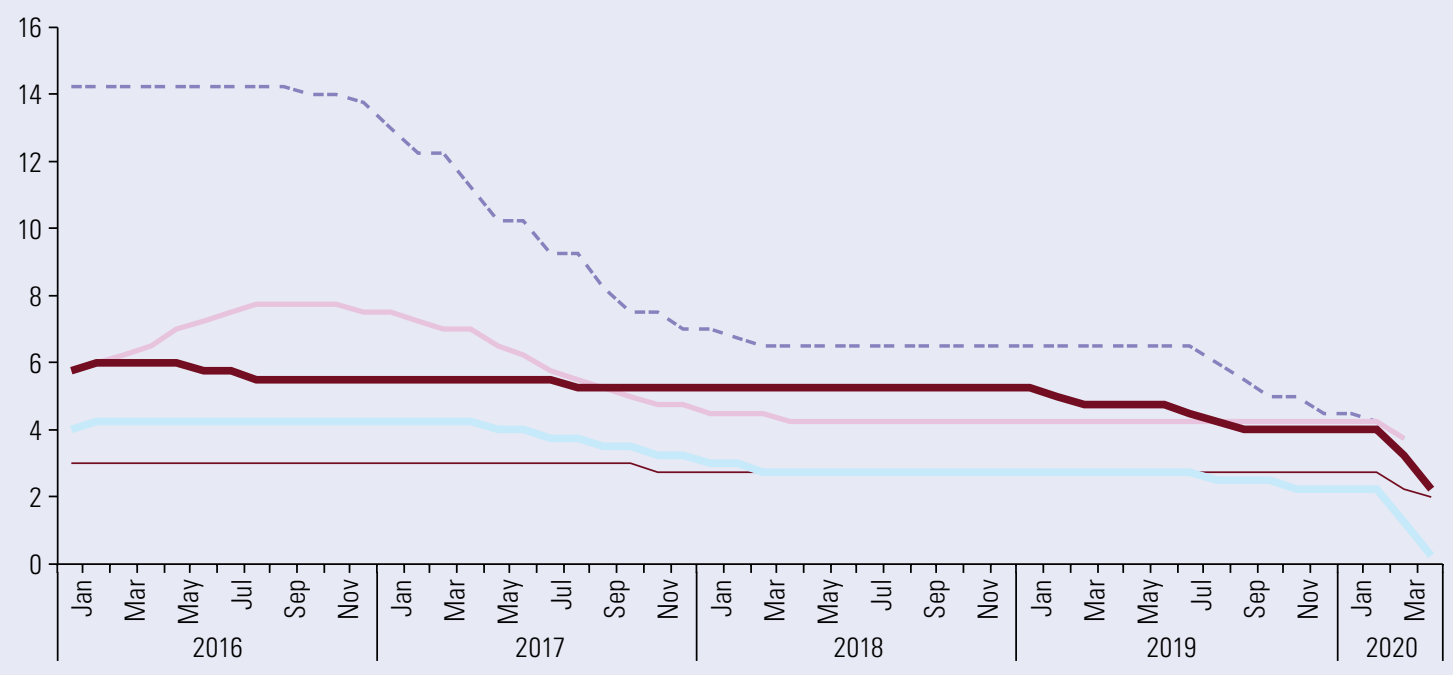

-- Brazil - Colombia - Paraguay Peru - Guatemala

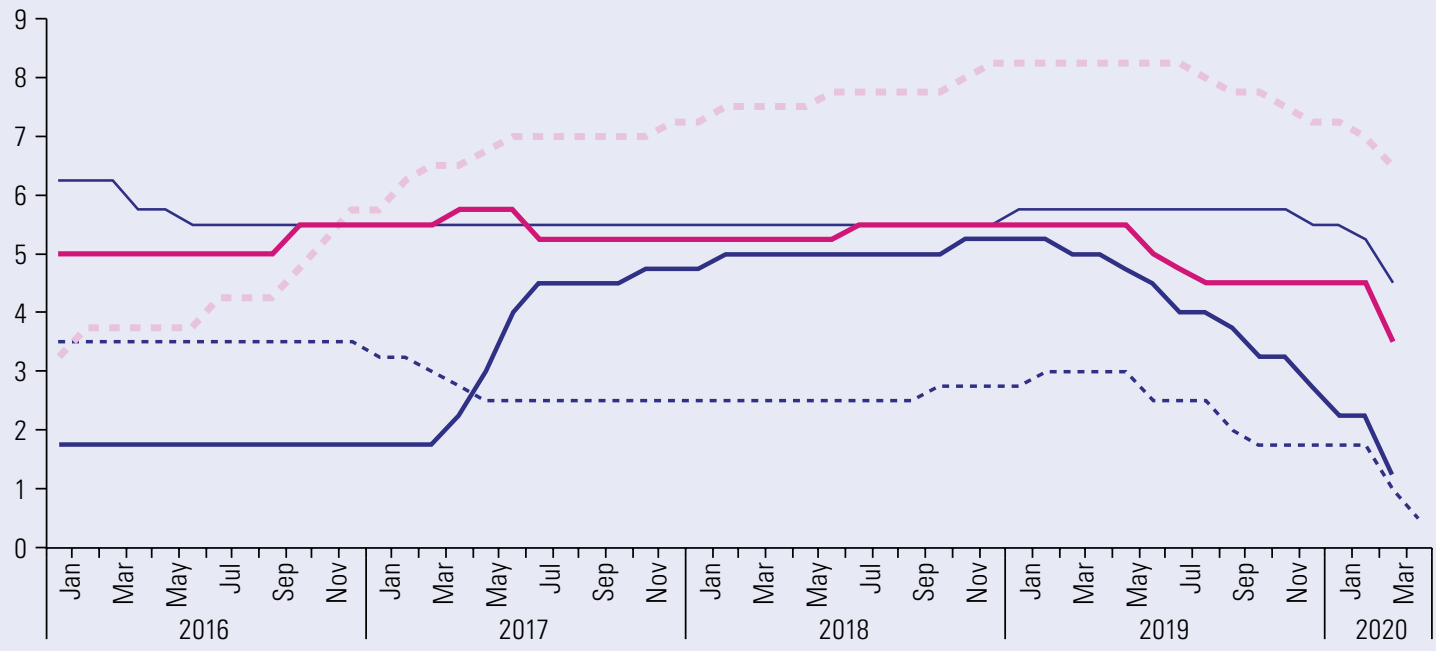

- Honduras - Dominican Rep. - -. Chile = Mexico - Costa Rica

Source: Economic Commission for Latin America and the Caribbean (ECLAC), on the basis of official figures.

\section{Growth projections for $\mathbf{2 0 2 0}$ for the countries of Latin America} and the Caribbean

\section{Methodology}

Growth forecasts were calculated by first estimating the effect of the global downturn on

the region's economies. The impact of lower growth in the United States and China was used as a proxy. Elasticities were calculated based on IMF (2019) data.

- The next step was to estimate the impact of the domestic supply shock caused by quarantine and social isolation measures that paralysed economic activity with varying severity across sectors. As mentioned earlier (see section B.2), the sectors were classified into three groups according to the extent to which they are likely to be affected by the containment measures. 
- For the projections, it was assumed that production began to be affected in the second half of March. The degrees of impact were determined on a monthly basis for each country from the time quarantines and other measures went into effect. The assumption - highly uncertain - is that the evolution of the pandemic will allow the authorities to gradually ease containment measures as from the third quarter, enabling a gradual recovery in production.

\section{ECLAC projects that the Latin American and Caribbean economy will contract by $5.3 \%$ in 2020 , increasing the number of poor by almost 30 million}

- In South America, the economy is expected to shrink by $\mathbf{5 . 2 \%}$. Some countries in this subregion are badly affected by the downturn in China, which is main market for their merchandise exports. This is true of Brazil, Chile, Peru and Uruguay, where more than $20 \%$ of exports (and more than $30 \%$ in Chile's case) go to China. This subregion will also be affected by falling commodity prices.

- The disruption of value chains will have a more severe impact on the economies of Brazil and Mexico, which have the region's largest manufacturing sectors. Brazil's economy is expected to contract by $5.2 \%$ and Mexico's by $6.5 \%$.

- The downturn is projected to be less sharp (-2.3\%) in the countries of Central America. As they are net importers of food and energy, lower commodity prices are not an issue. However, they have been severely affected by the decline in tourism and in activity in the United States, which is their main trading partner and largest source of foreign direct investment (FDI) and remittances.

- The Caribbean economies are expected to contract by $\mathbf{2 . 6 \%}$, dragged down by lower demand for labour-intensive tourism services.

- Projections also point to a significant deterioration in labour indicators in 2020.

- The unemployment rate is expected to climb to around $\mathbf{1 1 . 5 \%}$, up 3.4 percentage points from the $8.1 \%$ recorded in 2019 . This would bring the number of unemployed in the region to 37.7 million, an increase of nearly 11.6 million over the 2019 figure (26.1 million). These projections assume a fall of about $2.4 \%$ in the number of employed compared with 2019. In the Caribbean, where the tourism sector accounts for more than $50 \%$ of employment in many countries, the decline is likely to be sharper. These figures are significantly worse than those seen during the global financial crisis, when the region's unemployment rate rose from $6.7 \%$ in 2008 to $7.3 \%$ in 2009 (0.6 percentage points).

- The region's high rate of labour informality means that workers are extremely vulnerable to the effects of the pandemic and the measures to tackle it.

- The significant share of SMEs in job creation (accounting for more than $50 \%$ of formal employment) has amplified the adverse impacts on employment, as this sector has been badly hit by the crisis.

- Measures such as school closures and social distancing and the increase in the number of people falling ill will accentuate gender inequality by adding to the excessive burden of unpaid work performed by women.

- Households will be directly affected by the 5.3\% contraction in GDP and the 3.4 percentage point increase in unemployment, with lower incomes and greater difficulty in procuring sufficient resources to meet basic needs. 
Table 6 | Projected GDP growth rate for Latin America and the Caribbean, 2020

\begin{tabular}{|c|c|}
\hline & $\begin{array}{c}\text { GDP growth } \\
2020\end{array}$ \\
\hline Latin America and the Caribbean & $-5.3 \%$ \\
\hline Argentina & $-6.5 \%$ \\
\hline Bolivia (Plurinational State of) & $-3.0 \%$ \\
\hline Brazil & $-5.2 \%$ \\
\hline Chile & $-4.0 \%$ \\
\hline Colombia & $-2.6 \%$ \\
\hline Ecuador & $-6.5 \%$ \\
\hline Paraguay & $-1.5 \%$ \\
\hline Peru & $-4.0 \%$ \\
\hline Uruguay & $-4.0 \%$ \\
\hline Venezuela (Bolivarian Republic of) & $-18.0 \%$ \\
\hline South America & $-5.2 \%$ \\
\hline Costa Rica & $-3.6 \%$ \\
\hline Cuba & $-3.7 \%$ \\
\hline Dominican Republic & $0 \%$ \\
\hline El Salvador & $-3.0 \%$ \\
\hline Guatemala & $-1.3 \%$ \\
\hline Haiti & $-3.1 \%$ \\
\hline Honduras & $-2.8 \%$ \\
\hline Mexico & $-6.5 \%$ \\
\hline Nicaragua & $-5.9 \%$ \\
\hline Panama & $-2.0 \%$ \\
\hline Central America and Mexico & $-5.5 \%$ \\
\hline Central America & $-2.3 \%$ \\
\hline Latin America & $-5.3 \%$ \\
\hline Antigua and Barbuda & $-7.2 \%$ \\
\hline Bahamas & $-6.8 \%$ \\
\hline Barbados & $-5.8 \%$ \\
\hline Belize & $-3.9 \%$ \\
\hline Dominica & $-3.6 \%$ \\
\hline Grenada & $-7.3 \%$ \\
\hline Guyana & $56.4 \%$ \\
\hline Jamaica & $-5.3 \%$ \\
\hline Saint Kitts and Nevis & $-6.5 \%$ \\
\hline Saint Vincent and the Grenadines & $-3.6 \%$ \\
\hline Saint Lucia & $-8.1 \%$ \\
\hline Suriname & $-4.4 \%$ \\
\hline Trinidad and Tobago & $-5.0 \%$ \\
\hline The Caribbean & $-2.5 \%$ \\
\hline
\end{tabular}

Source: Economic Commission for Latin America and the Caribbean (ECLAC).

Note: Central America includes Cuba, the Dominican Republic and Haiti.

Against this backdrop, the poverty rate is expected to jump by 4.4 percentage points in 2020, from $\mathbf{3 0 . 3} \%$ to $\mathbf{3 4 . 7 \%}$, which translates into a further $\mathbf{2 8 . 7}$ million in poverty (see table $\mathbf{7}$ ).

Extreme poverty is expected to go up by 2.5 percentage points, from $11.0 \%$ to $13.5 \%$, which translates into an increase of 16 million people.

- Income distribution is also likely to worsen. Higher unemployment will raise the Gini coefficient by between $1 \%$ and $2 \%$, even before considering the additional rise in inequality stemming from the fall in employment income, which affects lower-income households more severely. 
Table 7 | Latin America: poverty and extreme poverty in a scenario of a $5.3 \%$ drop in GDP and a 3.4 percentage point increase in unemployment in 2020

(Millions of people and percentages)

\begin{tabular}{lrcc}
\hline Year & $\mathbf{2 0 1 8}$ & $\mathbf{2 0 1 9}$ & $\mathbf{2 0 2 0 ^ { \mathrm { a } }}$ \\
\hline Population & 607.7 & 613.5 & 619.2 \\
\hline Poverty & & & \\
\hline \multicolumn{1}{l}{ Latin America (18 countries) } & 180.6 & 186.0 & 214.7 \\
\hline Rate & $29.7 \%$ & $30.3 \%$ & $\mathbf{3 4 . 7} \%$ \\
\hline Extreme poverty & & & \\
\hline Latin America (18 countries) & 62.5 & 67.5 & $\mathbf{1 3 . 5 \%}$ \\
\hline Rate & $10.3 \%$ & $11.0 \%$ & \\
\hline
\end{tabular}

Source: Economic Commission for Latin America and the Caribbean (ECLAC).

a These estimates are preliminary and do not take into account the different impacts on certain production sectors or the employment created in each of those sectors.

\section{E. Macroeconomic policy challenges for continuing to mitigate} the effects of the crisis

- The fiscal packages announced in the region are the first response to the socioeconomic impact of the pandemic. Additional efforts will be required as the magnitude of the crisis grows, and it will therefore be necessary to expand the fiscal space, which requires access to financing on favourable terms.

- An increasing number of countries in the region have requested emergency financing from international financial institutions such as the International Monetary Fund (IMF), the World Bank, the Inter-American Development Bank (IDB) and the Development Bank of Latin America (CAF), which have expanded access to credit for their members. It is important that these institutions continue to provide low-cost, expeditious lines of credit, in addition to reviewing the conditionalities for emergency financing and adopting greater flexibility in their policies on concessional lending and the graduation of middle-income countries.

- The fiscal space could be significantly expanded by debt forgiveness and relief, including for middle-income countries in the region that require it. Highly indebted economies must be allowed to benefit from official debt relief or generous debt standstills, as well as debt restructuring. It is urgent to address the debt problem and this effort must be led by official creditors, so that private creditors will then follow suit. Where debt is a structural feature of the respective economy, debt relief should be combined with innovative financing mechanisms. Since, in most cases, some creditors belong to the private sector, an international sovereign debt restructuring mechanism needs to be set up.

Other measures to expand the fiscal space and improve access to financing include revising procyclical fiscal rules and responsibility mechanisms - which focus only on spending and not on income- and prevailing upon rating agencies to factor into their risk assessment methodologies the fact that the deterioration in the countries' fiscal capacities to face the crisis is extraordinary and temporary.

The region's central banks have announced "non-conventional measures" to expand liquidity, including the purchase of public and private assets. This will require stronger coordination between fiscal and monetary authorities to finance the stimulus packages announced, either by directly purchasing securities issued by the public sector or by using external assets to finance increased spending.

Coordination among stakeholders is required to determine how and when to "normalize" monetary policy in the region. Greater coordination is also needed between fiscal and monetary policy, as well as between central banks and banking oversight and regulatory bodies, to ensure that these resources are channelled to households and productive sectors that need them and do not flow into the reserves of financial institutions or into external assets. 
Given the magnitude of the shocks, it is necessary to adapt the macroprudential tools for mitigating exchange-rate volatility and excessive currency depreciations. Developing countries and emerging markets have found their access to foreign exchange, particularly to dollars, increasingly limited. The swap lines set up between the United States Federal Reserve and the central banks of Brazil and Mexico is a first step, but the rest of the region is not included in this support mechanism.

- An additional way to expand access to dollar liquidity for all countries would be through the issuance of Special Drawing Rights (SDRs) on a large scale, possibly even larger than in 2009, when IMF issued US\$250 billion in SDRs to help combat the global financial crisis, as proposed by the $\mathrm{G} 20$.

\section{F. Structural effects of the pandemic: the post-COVID 19 world}

- The pandemic has radically altered economic and social relations and its consequences will far outlast the health crisis. It is highly likely that the pandemic will accelerate changes that were already occurring in the configuration of global production and trade in the past decade.

- The model of globalization based on geographically highly dispersed international production networks was showing signs of depletion, for example in the secular stagnation of many economies, the loss of trade momentum and the great volatility seen since the global financial crisis.

- More recently, the unprecedented restrictions on international transport adopted by many countries have caused major disruptions in global value chains.

- Since the outbreak of COVID-19, new global manufacturing orders have suffered the largest drop in 11 years. The global index used by the manufacturing sector, the Purchasing Managers Index (PMI), confirms a deterioration in global production in the first quarter of 2020: in February alone, global manufacturing output tumbled by 7 points (IHS Markit, 2020).

- Although China has gradually resumed production, it faces supply-side constraints due to reduced imports from Europe and the United States, as well as very weak global demand. None of this points to a rapid recovery in global manufacturing. Global stocks of inputs fell sharply as a result of supply squeezes, with many countries reporting shortages of inputs, especially in sectors producing goods needed to respond to the health emergency.

- In sum, the amplification of the production crisis has exposed the vulnerabilities of interdependence between countries and between firms, and may lead to significant changes in the global organization of production.

- First, it has become apparent just how vulnerable international production networks are to large-scale unforeseen phenomena and, consequently, how much more resilient they need to be. For the multinational corporations at the core of these networks, this means diversifying networks of suppliers across countries and companies, preferably in locations closer to end markets (nearshoring), and relocating critical processes when economically feasible, through technologies such as additive manufacturing. There are already signs of movement in this direction in the world's major economies.

- Japan has allocated US\$2.2 billion of its COVID-19 economic stimulus package to helping its companies relocate production away from China.

- In the United States, the relocation rate peaked in 2019 amid trade tensions with China, while Mexico's share in United States manufacturing imports increased sharply relative to Asian suppliers (Kearney, 2020). The shocks caused by COVID-19 will likely accentuate both these trends.

- In the European Union, over 200 companies relocated their production between 2016 and 2019. Of these, $50 \%$ related to activities that had been offshored within the European Union itself, while China accounted for 32\% and India for 5\% (EUROFOUND, 2019). 
- Second, the crisis has forced companies to adapt their internal operations to social distancing measures. As robotics, automation and the mass use of teleworking platforms become more efficient, cheaper and easier to implement, the automation of some sectors and production processes is likely to accelerate, with impacts on employment.

- Third, with regard to global trade governance, COVID-19 has dealt a further blow to international cooperation and multilateralism, already weakened in recent years. Witness to this are the export restrictions on medical and health products and foodstuffs adopted by at least 60 countries across all regions. In this context, and consistently with a scenario of shrinking international supply networks, the main players in global trade will likely turn their efforts towards regional - rather than multilateral - agreements. Such a scenario would lead to more fragmented and conflict-ridden world trade, just when the ability of WTO to settle disputes among its members is already at its lowest ebb.

- In short, the pandemic may be expected to reinforce existing trends towards less trade and production interdependence among the world's major economies, particularly between the United States and Europe on the one hand, and China on the other. This process will be facilitated by advances in digitization and robotization, which reduce the relative importance of low labour costs as a factor of competitiveness. The net result will not be the reversal of globalization, but a more regionalized world economy, organized around three existing production poles: North America, Europe, and East and South-East Asia.

For Latin America and the Caribbean, the magnitude of the impact and the response capabilities will depend largely on the production structure of each economy, on the depths of its firms' involvement in value chains and on existing production capacities.

- As never before in the past 30 years, the region's prevailing model of engagement with the international economy — based on specialization in raw materials, assembly manufacturing and sun and sea tourism - is open to discussion today. The disruption of several global value chains has shown the risks of heavy regional dependence on imported manufactures. This is particularly evident in the severe limitations on the supply of essential products for combating COVID-19, following restrictions imposed by most of the region's major suppliers.

- In the automotive sector, the disruption of global chains has led to a delay in the supply of inputs, due to the closure of plants in China, Europe and the United States. The 12 motor vehicle firms operating in Mexico announced in late March that they would stop work due to the lack of essential parts and inputs. This closure resulted in a 25.5\% drop in the sector's total sales compared to March 2019 (AMIA, 2020). In Brazil, the shortage of parts and inputs has also slowed the sector's output, with a year-on-year drop of 21.1\% in March (ANFAVEA, 2020).

- In this context, it is all the more important to roll out industrial policies to enable the region to strengthen its productive capacities and generate new capacities in strategic sectors. These efforts could be facilitated in some countries by new investment freed up by the shortening of the supply chains of multinational companies, especially in the United States.

- In the international context that appears likely after COVID-19, production regionalization processes will be increasingly important. Regional integration will have a key role to play in the development strategies of the countries of Latin America and the Caribbean. An integrated market of 650 million people would act as major insurance against supply or demand shocks from outside the region. It would also help achieve the scale required to make new industries viable, and to foster shared production and research networks among the various countries and subregions.

- The foregoing analyses produce conclusions that are harsh, but clear:

- The region will suffer the worst crisis in its history in 2020, with a 5.3\% drop in GDP (see figure 12). A contraction of comparable magnitude has not occurred since the Great Depression of $1930(-5 \%)$ or even since $1914(-4.9 \%)$. 
- The crisis will have major medium-term effects on the reorganization of production and international trade in terms of location and technology. At least three possible scenarios are still open: the continuation of globalization, but on the basis of new models of governance that are more receptive to multilateralism and the correction of inequalities between countries; solutions of exclusively national scope; or the strengthening of regionalization.

- For the great majority of Latin America and Caribbean countries, purely national solutions will not be viable owing to economies of scale, technology and learning.

- A new form of globalization with inclusive and sustainable governance may be the best solution, but in order to participate actively in this new configuration, Latin America and the Caribbean must achieve productive, trade and social integration. To this end, our countries must coordinate on macroeconomic and production matters in order to negotiate the conditions for the new normality. During the current crisis and also for the medium-term, financing for a new pattern of development with equality and environmental sustainability is of the essence.

Figure 12 | Latin America: annual GDP growth rate in real terms, 1901-2020 (Percentages)

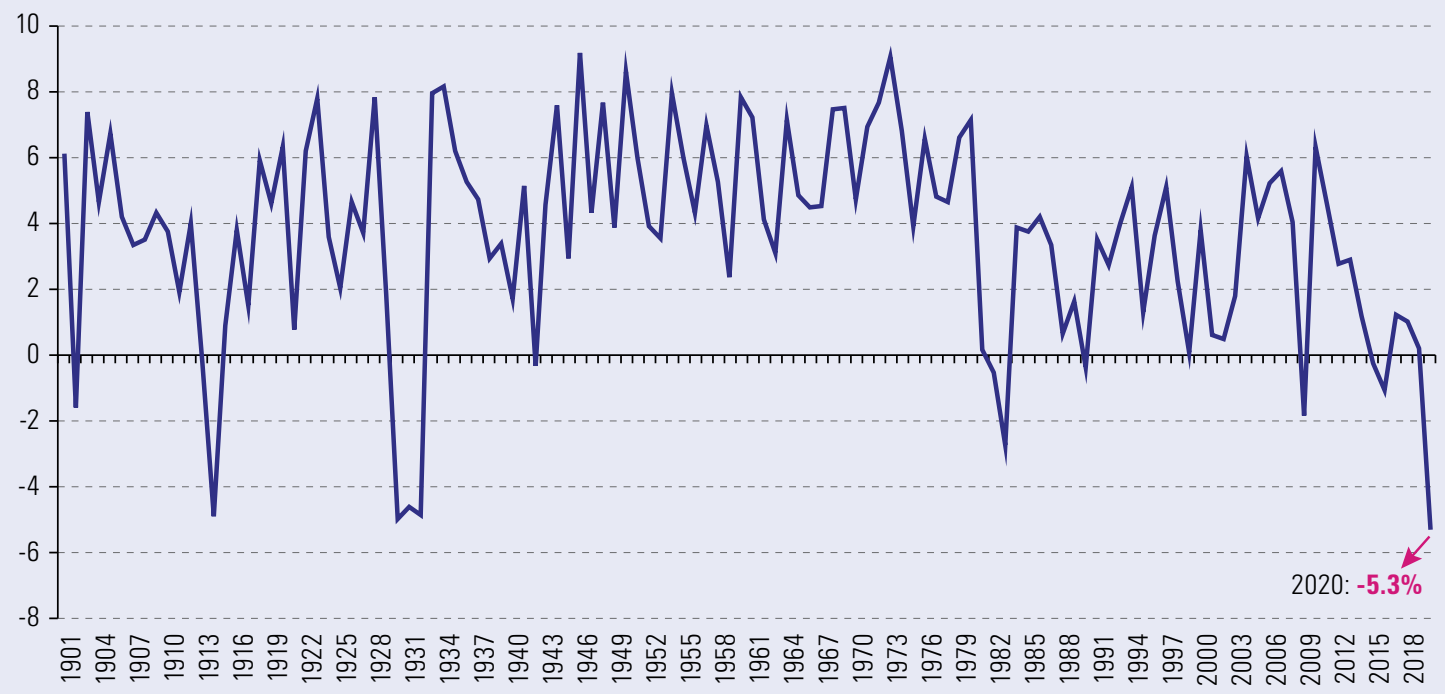

Source: Economic Commission for Latin America and the Caribbean (ECLAC), on the basis of data from Groningen Growth and Development Centre, Maddison Project Database [online] https://www.rug.nl/ggdc/historicaldevelopment/maddison/releases/maddison-project-database-2018 up to 1950, and official figures from 1950 up to 2019.

Note: The figure shown for 2020 is an ECLAC projection. 


\section{Bibliography}

AMIA (Mexican Automotive Industry Association) (2020), "Reporte de ventas de vehículos ligeros nuevos por marca en marzo de 2020", 2 April [online] www.amia.com.mx.

ANFAVEA (National Association of Motor Vehicle Manufacturers of Brazil) (2020), "Avanço da Covid-19 derruba números da indústria automotiva em quase 90\% no final de março", 6 April [online] http:// www.anfavea.com.br/docs/Release \%20-\%20Avan\%C3\%A70\%20da\%20Covid-19\%20derruba\%20 n\%C3\%BAmeros \%20da\%20ind\%C3\%BAstria\%20automotiva\%20em\%20quase \% 2090\% 20no\% 20 final\%20de\%20mar\%C3\%A7o.pdf.

BIS (Bank for International Settlements) (2020), "Debt securities statistics" [online] https://www.bis.org/ statistics/secstats.htm.

ECLAC (Economic Commission for Latin America and the Caribbean) (2020), "Latin America and the Caribbean and the COVID-19 pandemic: economic and social effects", COVID-19 Special Report, No. 1, 3 April, Santiago.

EUROFOUND (European Foundation for the Improvement of Living and Working Conditions) (2019), "European Reshoring Monitor" [online] https://reshoring.eurofound.europa.eu/.

IHS Markit (2020), "Manufacturing downturn deepens outside of China", 1 April [online] https://ihsmarkit. com/research-analysis/manufacturing-downturn-deepens-outside-of-china-April2020.html.

IIF (Institute of International Finance) (2020a), Capital Flows Report: Sudden Stop in Emerging Markets, 9 April.

(2020b), "Global Debt Monitor: COVID-19 lights a fuse", 6 April [online] https://www.iif.com/Portals/0/ Files/content/Research/Global\%20Debt\%20Monitor_April2020.pdf.

(2020c), "LatAm views: deep recession", 13 April [online] https://www.iif.com/Portals/0/Files/content/ Research/04_13_2020_latam_views.pdf.

IMF (International Monetary Fund) (2019), Regional Economic Outlook. Western Hemisphere: Stunted by Uncertainty, Washington, D.C.

Kearney (2020), "Trade war spurs sharp reversal in 2019 Reshoring Index, foreshadowing COVID-19 test of supply chain resilience" [online] https://www.kearney.com/operations-performance-transformation/ us-reshoring-index.

Pineda, E. and A. Musacchio (2020), "Solving the state-owned enterprises puzzle in Latin America and the Caribbean", Banco Interamericano de Desarrollo (BID), 18 January [online] https://blogs.iadb.org/gestionfiscal/en/solving-the-state-owned-enterprises-puzzle-in-latin-america-and-the-caribbean.

United States Bureau of the Census (2018), "American Community Survey (ACS)" [online] https://www. census.gov/programs-surveys/acs.

UNWTO (World Tourism Organization) (2020), "Impact assessment of the COVID-19 outbreak on international tourism", 24 March [online] https://webunwto.s3.eu-west-1.amazonaws.com/s3fspublic/2020-03/24-03Coronavirus.pdf.

This Special Report is the second in a series by the Economic Commission for Latin America and the Caribbean (ECLAC) on the evolution and impacts of the COVID-19 pandemic in Latin America and the Caribbean, and will update the economic and social analysis as the relevant information becomes available. The preparation of the Report will be headed by the Executive Secretary of ECLAC, Alicia Bárcena, with the technical support of the Office of the Deputy Executive Secretary, Mario Cimoli, and the substantive divisions responsible for the topics addressed, as well as the subregional headquarters and country offices of ECLAC.

Copyright (C) United Nations, 2020

Economic Commission for Latin America and the Caribbean (ECLAC)

E I I C Comisión Económica para América Latina y el Caribe (CEPAL)

www.eclac.org 